\title{
New results in analysing the environmental impacts of tourism and sports
}

\author{
L. David, Zs. Szilagyi \& Z. Baros \\ Károly Róbert College, Hungary
}

\begin{abstract}
In the past few decades, interest in the environment has reached a peak as the public has become aware of the extent of the human impact on physical systems. A proliferation of degrees has followed this wave of 'environmentalism', with them focusing on natural areas and the damage caused by human impacts. Within the system of the physical environment, the transformation of any of its elements, including relief, has an impact on the mechanism of the whole system, and can trigger several, mostly unfavourable transformations. However, the extent of such impacts on the environment, and within this we include relief related to recreation activities, compared to that of other sectors (e.g. industry, agriculture) is rather small. However, due to the continuously growing popularity of these sectors, more attention should be paid to planning that takes the complicated relations of the environment and activities into account, apparent as a result of the discovery of new destinations. Those looking for leisure and, in the meantime, intending to enjoy nature, will also have to become environmentally sound users. The impact of recreation activities on the relief can come into force in many ways. In either studies carried out at a given area or comprehensive studies that also use the previous results, the demand for a multidisciplinary approach resultant from the characteristics of this topic represents a great challenge to the experts.
\end{abstract}

Keywords: tourism, sports, environmental impacts, anthropogenic geomorphology.

\section{Introduction}

Mankind's demand for recreation, the pleasant spending of free time, can be traced back to Ancient times. Based on the attractiveness of emerging from 
everyday routines, a service network indispensable to the development of mass tourism driven by motivation, discretional incomes and free time as well as sports becoming mass phenomena, has been built up through most of the world in the $20^{\text {th }}$ century. Due to our accelerated lifestyle associated with increased stress, tourism and sport with their immense development have become two of the most requested free-time activities of the citizens in the developed countries since the last third of the $20^{\text {th }}$ century. Regarding the complexity of factors influencing the development of these two sectors, various estimations can be heard in connection with the future of tourism and sport. It cannot be argued, however, that the conjuncture of the need for recreation, considered as the basic and the most popular motivation for travelling and sport, is undiminished. Recreation conventionally means the refreshment and reproduction of mankind's working ability. Based on the characteristics (and means) of activity, intellectual and physical recreation can be distinguished. Intellectual recreation is a mostly active (participatory, generative) activity; however, this consequentially becomes a passive (spectator, recipient or receptive) activity involving the matter of culture, entertainment and civilisation. Physical recreation means a (physical, manual) work (activity) carried out during one's free time (voluntarily) [7].

\section{Impacts related to motorsports}

Motorized sports have recently gained a worldwide and ever growing popularity resulting in the availability of a wide range of activities that can be classified into the following categories:

- Water or land (off-road or concrete track) motorsports

- Seasonal or all-the-year-round motorsports

For both, primary (resulting from the activity itself and from the establishment of the necessary infrastructure) and secondary (induced by the activity) impacts on the surface should be distinguished. The surface-forming impact caused by the constructions related to motorsports with tracks can be parallel to the consequences of the construction of roads. The topographical imbalance is accentuated in a relatively small area, mostly in the decay of the stability in the primary landscape, by the establishment of unusually steep and long slopes thus increasing erosion. The earthworks of roads - in addition to being surface- and landscape-forming factors en mass - also have an indirect impact on natural landscape-forming and microclimate influencing processes [3]. Recently, motorisation (also referred to as Toyotarisation) has been also seen as triggering sand and dust storms becoming more frequent in desert areas, as safari programmes with jeeps can also contribute to the disruption of the surface [4]. Additional damage is made by visitors' trampling, access roads, facilities and the construction of the associated infrastructure. This could be especially high at times of races (concentrated use) where spectators leave the established and designated areas, e.g. to take photographs. The degree of biophysical impact will depend on the location, intensity and duration of the activities themselves. Environmental response will vary in accordance to individual species/ecosystem 
resistance and resilience. The amusement offered by off-road driving is now available to a greater number of participants. For them, the feeling of freedom, driving at illegal locations is of high priority regardless of its consequences being widespread as well as making the management of such impacts rather difficult.

\section{Recreation activities triggering or increasing erosion}

The impacts of recreation activities regarding the physical environment to their attractiveness are usually associated with several groups of activities. On the grounds, along pathways and in areas not touched by designated routes, treading is a universal problem leading to the soil compaction, and erosion. As a result of compaction, porosity and permeability are reduced and runoff increased. Water can easily entrain soil particles triggering erosion. Meanwhile, as an effect of high pressure, herbaceous plant cover protecting the soil gets damaged very soon, and as a result of time periods with precipitation, the surface of the soil can be soggy. By walking around the sections poorly passable, the widening of the paths starts, on the one hand, whereas soil erosion speeds up to a significant extent on unprotected surfaces. This, in many cases, leads to creating a covered road surface.

The most remarkable impact of erosion caused by recreation activities can be observed in highlands. These areas, because of their steep slopes, shallow soil cover, especially at regions receiving more precipitation are extremely susceptible. Under a colder mountainous climate at a higher elevation above sea level, the vegetation is more susceptible and tends to need a longer time for revival. Despite these unfavourable endowments, high mountains are under enormous demand. Following the melting of snow it becomes visible that long, bare soil strips run on the slopes - downhill courses. Damage caused by grassskiing not taking snow conditions into account is not significant yet.

In mountainous areas footpath erosion caused by hikers is an increasingly relevant environmental problem. Karancsi [6] claims that in the nature conservation area of Britain's Lake District attracting approximately 14 million visitors each year, footpath erosion often leaves behind huge scars observable even on satellite images in the landscape. According to the observations carried out in several national parks in Britain, when the angle of slope of a tourist route reaches 10 degrees, following the destruction of the natural vegetation cover, soil erosion starts on the surface. Other highland areas suitable for hiking are obviously exposed to similarly great effects, too. According to the measurements of Hartley [5], 5-10 tourists per week can cause the reduction of the diversity of species by $10 \%$, a potential increase in the extent of bare soil surface by 10 to $20 \%$ and in the compaction of the soil by 10 to $40 \%$.

The impacts of the use off-road vehicles and all-terrain vehicles (motorcycles, four-wheel-drive vehicles, etc.) on the surface should be investigated in details (Fig. 1). The use of off-road vehicles and motorcycles, by creating or widening of trails (non-system routes), has an impact on soils, vegetation, wildlife and social conditions. 


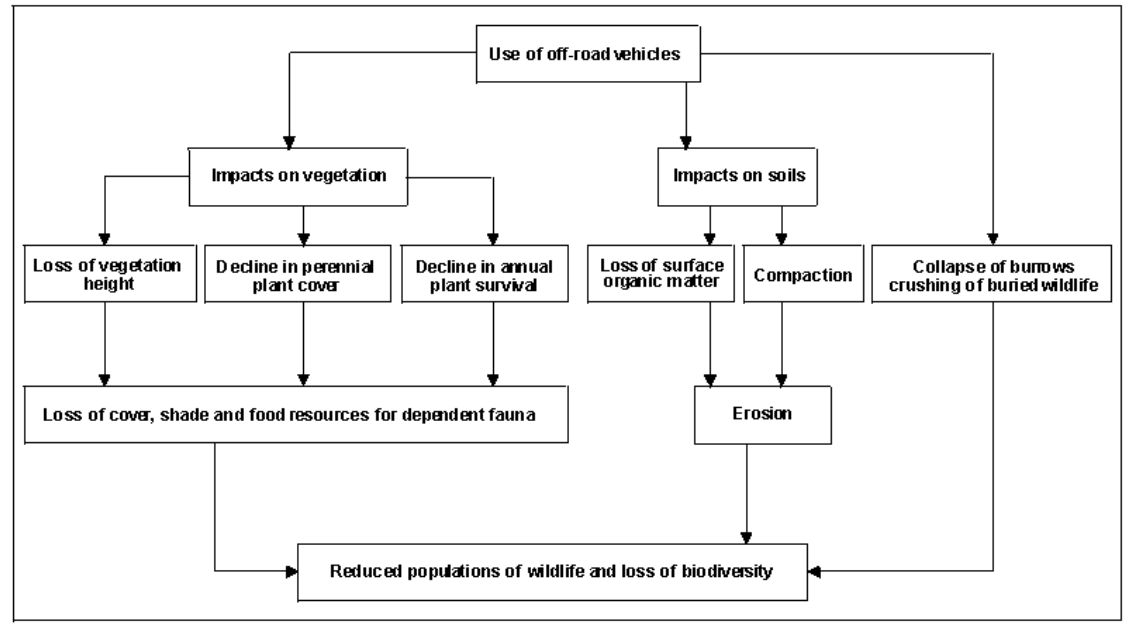

Figure 1: The impacts of off-road-vehicles on the surface (derived by Newsome et al. [8] from Edington and Edington [2]).

\section{Conclusions}

In the past few decades, interest in the environment has reached a peak as the public has become aware of the extent of the human impact on physical systems (Fig. 2).

A proliferation of degrees has followed this wave of 'environmentalism', with them focusing on natural areas and the damage caused by human impacts. Environmental geomorphology is the study of the special interaction between humans and the geographical environment which includes not only the physical constituents of the Earth, but also the surface of the Earth, its landforms and in particular the processes which operate to change it through time. In the research of the physical environment two, frequently intertwining trends are prominent since the 1970s. One of them investigates the changes in the physical environment induced by human economic intervention (often undesirable) along with their counter-effects. The other aims at the quantitative and qualitative survey of the resources and potentials of the physical environment as well as the evaluation of also regionally varying geographical potentials. Anthropogenic geomorphology is a new approach and practice to study our physical environment, as in the 1980s the more and more urgent demands from society against geography - even more manifested due to the scientific-technical revolution - underlined the tasks to promote efficiently the rational utilization of natural resources and potentials, to achieve an environmental management satisfying social requirements and opportunities. At the same time, anthropogenic geomorphology is a new challenge for geomorphologists, since environmental problems influence several branches of science. Anthropogenic 
geomorphology studies the huge - and more and more increasing - number of landform associations of extreme variety depending on the given way and aim of their creation, which have been made by the human activity (for example tourism and sport activities). The discipline also studies the surface changes induced by these forms; moreover, predicts the consequences of disturbance of the original equilibrium, and makes recommendations for preventing damages. Therefore, anthropogenic geomorphology can be also regarded as an applied discipline, which helps to solve both social-economic as well as environmental and natural protection problems [9].

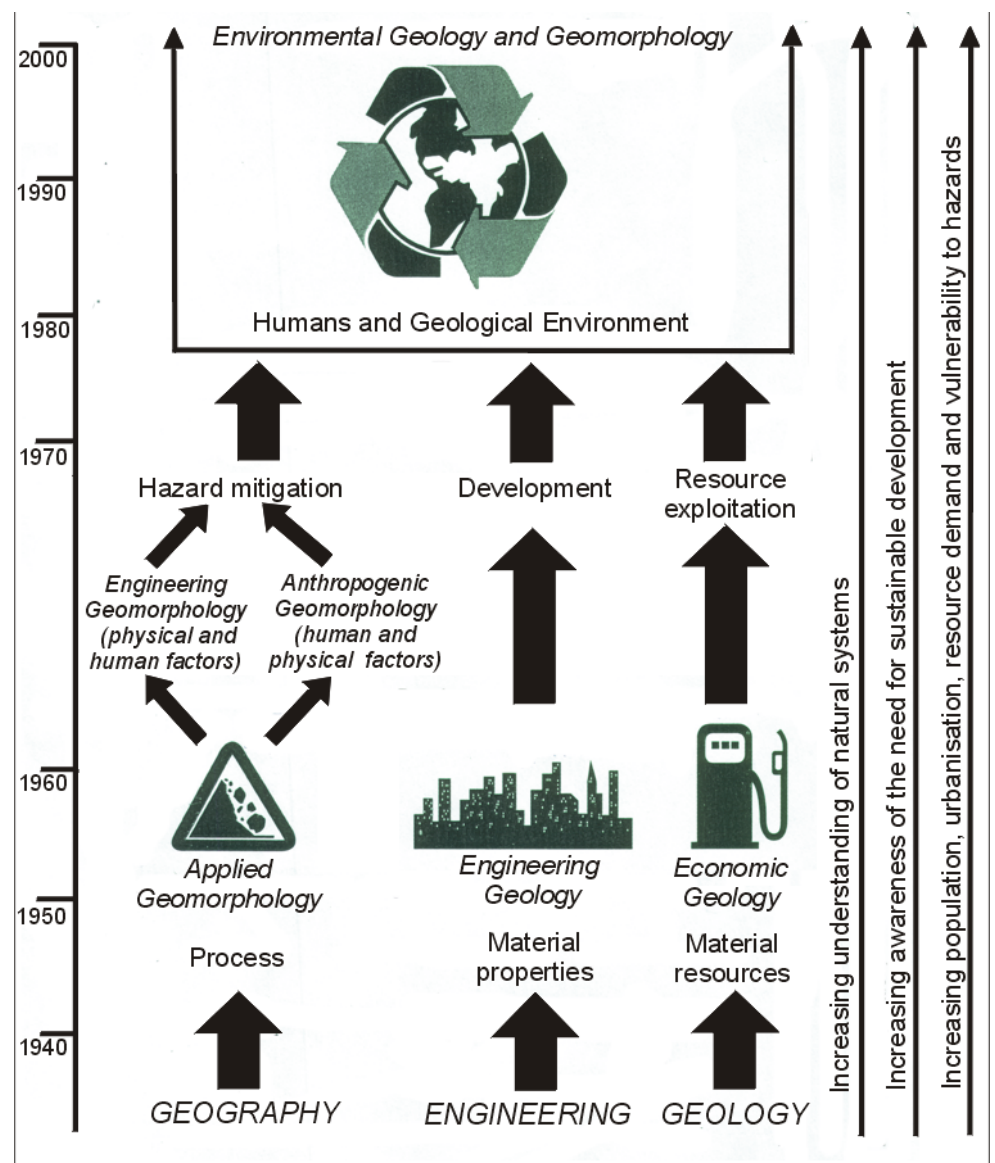

Figure 2: Development and differentiation of Earth sciences (including anthropogenic geomorphology) and their connection with environmental problems (Bennett and Doyle [1], modified by Dávid and Baros, 2006 - in Szabó and Dávid, eds. [9]). 


\section{References}

[1] Benneth, M. R. \& Doyle, P. (1999): Environmental Geology, John Wiley and Sons, Chichester, 501 p. 1999.

[2] Edington, J.M. \& Edington, M.A. (1986): Ecology, Recreation and Tourism, Cambridge: Cambridge University Press. 1986.

[3] Erdősi, F. (1987): A társadalom hatása a felszínre, a vizekre és az éghajlatra Mecsek tágabb környezetében (The impact of society on the surface, waters and climate in the broader environment of the Mecsek Mountains), Budapest, 228 p. 1987.

[4] Goudie, A. ed. (2004): Encyclopaedia of Geomorphology, Routledge, London, 1156 p. 2004.

[5] Hartley, E.A. (1976): Man's effects on the stability of alpine and sub-alpine vegetation in Glacier National Park, Montana. PhD dissertation, Duke University, North Carolina, 170 p. 1976.

[6] Karancsi, Z. (2000): Természetvédelem kontra turizmus: "Meglaposodott" brit nemzeti parkok (Nature conservation vs. tourism: 'Flattened' national parks in Great Britain), Földgömb, Vol. 18. No. 4. Földgömb '99 Kft., Budapest, pp. 30-37. 2000.

[7] Kovács, T. (2002): A rekreáció fogalma, értelmezése (The conception and interpretation of recreation). In.: Dobozy, L. ed.: Válogatott tanulmányok a rekreációs képzés számára (Selected studies for training in recreation), Magyar Sporttudományi Társaság, Budapest, 22-44. p. 2002.

[8] Newsome, D., Moore, S.A. \& Dowling, R.K. (2002): Natural Area Tourism - Ecology, Impacts and Management, Channel View Publications, Clevedon-Buffalo-Toronto-Sydney, 340 p. 2002.

[9] Szabó, J. \& Dávid, L. (szerk.) et al. (2006): Antropogén geomorfológia (Anthropogenic Geomorphology), Debreceni Egyetem, 318 p. 